Marina N. Yakovleva

student

Scientific adviser

Tatyana L. Fomicheva

candidate of economic sciences, associate professor FSFEI of HE "Financial University under the Government of the Russian Federation" MoscowMoscow

DOI $10.31483 / r-97317$

\title{
APPLICATION OF ARTIFICIAL INTELLIGENCE IN THE BANKING SECTOR
}

Abstract: this article is devoted to the study of the role of artificial intelligence in the banking sector. Today, the introduction of new technologies in all spheres of life is a very relevant topic. The article reveals the concept of artificial intelligence as a factor in the development of the banking sector in particular and the economy as a whole. An overview of the use of the artificial intelligence system in banks in Russia and the world is presented.

Keywords: artificial intelligence, banks, banking, Finance, banking system.

Яковлева Марина Николаевна

студентка

Научный руководитель

Фомичева Татьяна Леонидовна

канд. экон. наук, доцент

ФГОБУ ВО «Финансовый университет

при Правительстве Российской Федерации»

г. Москва

ИСПОЛЬЗОВАНИЕ ИСКУССТВЕННОГО ИНТЕЛЛЕКТА

В БАНКОВСКОЙ СИСТЕМЕ 
Аннотация: статья посвящена изучению роли искусственного интеллекта в банковской системе. Применение новых технологий во всех сферах жизни является очень актуальной проблемой. Работа раскрывает понятие искусственного интеллекта как фактора развития банковского сектора и экономики в целом. Авторами приведены общие положения об использовании искусственного интеллекта в банках России.

Ключевые слова: искусственный интеллект, банки, банковская деятельность, финансы, банковская система.

Currently, there is an active introduction of artificial intelligence (AI) in the banking sector. This does not happen by chance, because AI increases productivity growth, helps reduce error and deepens personalization. The beginning of the introduction of AI into the activities of banks was laid back in the 1950s, when machines were just beginning to master tasks previously performed by humans. Now AI is involved in banks everywhere: in risk analysis, control departments, technical support, marketing, etc.

The article will consider various components of the banking platform of the new generation, based on artificial intelligence: chat bots, roboediting, various individual offers and increased loyalty, InternetofThings, antifrode and operational efficiency. Specific examples of the use of AI by banks will also be given (the experience of Sber, Points, BankofAmerica, Bankof Tokyo-Mitsubishi UFJ and some other financial organizations).

One of the widespread uses of AI is currently chatbots, or virtual interlocutors. In the process of interaction with a person, a chatbot is able to generate responses to a request based on a complex multivariable algorithm for perceiving and processing information. For banking, chatbots are used not only to quickly answer customer questions and inform about new products and services, but also for other tasks, for example, to provide financial advice to the client, take into account his personal finances, show the current exchange rate, etc. 
Roboediting becomes an alternative to banking consultants and various online transactions with money [1] The greatest advantage of this application of AI is given in the field of online trading due to the speed in the execution of applications, monitoring a large amount of relevant information and the ability to work with a large number of transactions at the same time. Also in general, this contributes to increasing the financial and investment literacy of the population. Roboedvizers are available on the desktop or in the form of mobile applications. For example, Sber has a Sberbank-Investor application, where roboedweisers act as a portfolio manager, can identify the risks of planned investments, and also choose the optimal investment strategy [2].

In addition to all of the above, artificial intelligence is also able to promote the product by selecting recommendations for banking products based on the use of customer knowledge from social networks. AI recommendations can give not only to individuals, but also to businesses. For example, it can determine the B2B of a client's relationship with the subsequent recommendations of new counterparties, or simulate financial risks for small businesses (such risks include default, cash gap, etc.), and then, based on modeling, offer recommendations on a targeted strategy products to it [3].

AI is also used in InternetofThings. For banking, we can call smart insurance for individuals, for example, in the field of medicine or car loans. This is actively used by the Sberbank-Insurance system. Although insurance is not exactly a banking sector, there is still a relationship.

One of the key applications of AI is antifrode, which helps to detect external and internal threats to the client. The tasks of AI in this area include the identification of signs of the use of the client's plastic card by third parties, the identification of fictitious salary projects and unauthorized expenditure transactions on customer accounts, abuse during conversion operations, etc. That is, we can say that AI helps in the audit work.

In general, artificial intelligence helps to increase overall operational efficiency by identifying and adjusting transaction deviations, optimizing the operation of collection services, monitoring the failure of banking infrastructure (ATMs, IT resources), and managing the quality of consultation. 
In the Russian Federation, the bank that most widely uses artificial intelligence is Sber. According to the data of the annual report for 2018, published in April 2019, Sberbank increased the efficiency of the back office by $25 \%$ due to robotization of processes and reduction of manual labor. According to Sberbank, the speed of individual client operations increased 4-10 times after the introduction of AI. «Smart products change the credit process: corporate customers can get a loan in 7 minutes, and private customers spend minutes on filling out a questionnaire when applying for a loan online," Sberbank notes in the annual report.

It is worth noting that the Sberbank-Investor application mentioned above largely uses artificial intelligence.

The digital bank «Tochka» known among entrepreneurs on December 12, 2019 announced the introduction of artificial intelligence that can predict the blocking of the account by the Federal Tax Service. If the algorithm determines the probability of blocking at $80 \%$ or higher, then the client will receive an email warning about this, as well as recommendations that will help avoid problems with the account. Artificial intelligence simultaneously takes into account many factors, from the age of the company or individual entrepreneurs to the presence of account suspensions in the past and even the age of the head of the company. If the algorithm detects the probability of blocking from $80 \%$ or higher, the client is notified about this by e-mail, accompanying the letter with recommendations, which may include reconciliation with the tax, verification of the fact of submission of the report itself, confirmation of receipt of documents by the tax authorities, etc.

The experience of foreign banks in the use of $\mathrm{AI}$ is also very diverse, here you can distinguish the practice of BankofAmerica and several Japanese banks.

«BankofAmerica» in June 2018 announced the beginning of the use of machine learning in the analysis of foreign exchange strategies. The reason for this was the unstable political situation in Italy in early June 2018, experts feared for the emergence of another financial crisis on this basis. The tasks of AI include the preparation of a forecast of the relations of the euro-dollar currency pair. 
Large-scale automation did not bypass Japanese banks. For example, BankofTokyo-MitsubishiUFL plans to automate 9,500 work metas by fiscal year 2023 (many companies in Japan have a fiscal year ending at the end of March). Major financial institutions in Japan such as «SumitomoMitsuiFinancialGroup» and «MizuhoFinancialGroup» expect to minimize the number of personnel with functions that duplicate each other by using computational algorithms and new robotic processing systems (initially this robotic processing system was used by «MizuhoFinancialGroup» when entering data when opening an investment account [4].

The general trend is that artificial intelligence is taking an increasingly strong position in the banking sector by increasing productivity, expanding customer opportunities and reducing costs. It is likely that in a few years, artificial intelligence for the light of advanced machine learning will reach such heights that it can completely replace a person in most working positions.

\section{References}

1. Artificial intelligence in banks: prospects and advantages. URL: https://finexecutive.com/ru/news/iskusstvennyy_intellekt_v_bankah_perspektivy_i_preimushestva (retrieved from: 30.11.2020).

2. How does artificial intelligence work in banks. URL: https://fond.sk.ru/news/b/press/archive/2020/09/17/kak-iskusstvennyy-intellekt-rabotaet-v-bankah.aspx (retrieved from: 30.11.2020).

3. Artificial intelligence in banks. URL: https://www.tadviser.ru/a/331877 (retrieved from: 30.11 .2020$)$.

4. Areas of application of artificial intelligence in banks. URL: https://investoriq.ru/banki/iskusstvennyj-intellekt.html (retrieved from: 30.11.2020). 